\title{
Recent State of Research on the Life and Work of Carl Ditters von Dittersdorf in Poland
}

\section{Agnieszka Drożdżewska}

The music of the Viennese composer, violinist and Kapellmeister Carl Ditters von Dittersdorf (1739-1799), who spent almost 30 years of his life in Silesia, employed at the castle of the Bishop of Wrocław, Prince Philipp Gotthard von Schaffgotsch in Javorník on Jánský vrch (Johannisberg), was particularly valued in this region. It was here that Dittersdorf composed over 40 comic operas and singspiels which were successfully staged e.g. in Vienna, Brno or Weimar. In the composer's life, the Silesian period abounded also in oratorios, symphonies and chamber instrumental works. It is worth emphasizing that this artist experienced a peak of fame during his lifetime, which confirms the multitude of his work, recorded in the music collections of church and secular institutions in almost all of Central Europe. Dittersdorf's music was also known and performed in many Polish regions, although the artist never visited this country personally. Despite this, artistic contacts and musical influences, along with the popularization of works through numerous musical editions, made his compositions an important element of the repertoire of Polish theaters, as well as church and secular ensembles.

Intensified research on the life and work of Dittersdorf and the reception of his music in Poland began at the end of the 20th century in the musicological environment of the University of Opole by establishing scientific contacts with Professor Hubert Unverricht, a tireless researcher and propagator of the artist's work. An important event summarizing the recent research at that time was the International Interdisciplinary Symposium organized in Nysa on September 24-26, 1999. In addition to Czech, Slovak, German and Austrian researchers, the papers were presented by Polish scientists: Maria Zduniak, Fr. Piotr Tarlinski, Remigiusz Pośpiech and Wojciech Kunicki, discussing the issues of artistic contacts between the musician and Wrocław, the reception of his music in Poland, religious music and singspiel performance practice. The fruit of this conference was the first Polish monographic volume of works devoted to 
Dittersdorf. ${ }^{1}$ This collaboration resulted also in the volume of collected works by Hubert Unverricht, containing several dozen articles from the musicologist's achievements, including 16 papers devoted to the life and work of Dittersdorf. Bilingual edition prepared by Fr. Piotr Tarlinski made the access to the knowledge easier for Polish researchers. ${ }^{2}$

The first summary of the state of research on the music of Carl Ditters von Dittersdorf in Poland was made in 2000 by Remigiusz Pośpiech, analyzing the reception of his work in the Polish-Lithuanian Commonwealth in the 18th and the first half of the 19th centuries. ${ }^{3}$ This article is a highly valuable source of knowledge about the previous achievements of Polish musicologists in this field and one of the basic links for the content of this paper. Most of the cited works from before the year 2000 were taken from this paper.

The first mention of Dittersdorf's activity in Silesia appeared in 1980 in an article by Edward Krysta, however, based solely on the composer's autobiography. ${ }^{4}$ At the same time, Maria Zduniak began at the Academy of Music in Wrocław a research on the artist's contacts with Silesia and already in 1984 mentioned the presence of Dittersdorf's works in the repertoire of the Wrocław theater. ${ }^{5}$ She published the effects of her source research in the form of an extensive article on the composer's connections with Wrocław and Silesia, using many previously unknown sources, including masses and offertories from the collections of the Archidiocesan Library in Wrocław. ${ }^{6}$

Before the comprehensive research on individual genres of creativity was initiated in Silesian (Faculty of Theology, University of Opole, and then the Institute of Musicology of the University of Wrocław) and other Polish research centres, Dittersdorf's work had been recorded or mentioned in publications resulting from inventory activities conducted since the 1960s. Knowledge about resources of his music is steadily increasing by his compositions being regularly registered in the RISM database. Its current status indicates the presence of Dittersdorf's

1 Carl Ditters von Dittersdorf. Z życia i twórczości muzycznej, ed. Piotr Tarlinski, Hubert Unverricht (Opole: Redakcja Wydawnictw Wydziału Teologicznego Uniwersytetu Opolskiego, 2000).

2 Hubert Unverricht, De Musica in Silesia. Zbiór artykutów, ed. Piotr Tarlinski (Opole: Redakcja Wydawnictw Wydziału Teologicznego Uniwersytetu Opolskiego, 2007).

3 Remigiusz Pośpiech, „Recepcja muzyki Carla Dittersa von Dittersdorfa w Polsce w XVIII i pierwszej połowie XIX wieku” in Carl Ditters von Dittersdorf. Z ̇̇ycia, 229-248.

4 Edward Krysta, „Działalność Karola Ditters von Dittersdorfa na Śląsku” in Tradycje ślaskiej kultury muzycznej, t. III, ed. Tadeusz Natanson, Walentyna Węgrzyn-Klisowska, Maria Zduniak (Wrocław: Państwowa Wyższa Szkoła Muzyczna we Wrocławiu, 1981), 209-224.

5 Maria Zduniak, Muzyka i muzycy polscy w dziewiętnastowiecznym Wroctawiu (Wrocław: Zakład Narodowy im. Ossolińskich, 1984 = Monografie Śląskie XXXVII), 30.

6 Maria Zduniak, „Carl Ditters von Dittersdorf - Ślązak z wyboru” in Arcana musicae, ed. Marta Szoka (Łódź: Akademia Muzyczna im G. i K. Bacewiczów, 1999), 87-92; Maria Zduniak, „Carl Ditters von Dittersdorfs Beziehungen zu Breslau" in Carl Ditters von Dittersdorf. Z życia, 31-56. 
music in 13 archives and libraries, with total amount of ca. 200 sources. ${ }^{7}$ Under the observation of Polish musicologists are also collections now kept abroad: from Cistercian abbey in Obra (now in Bayerische Staatsbibliothek in München (D-Mbs) and, essential for the research on Dittersdorf, former collection of the ducal castle in Oleśnica (Oels) held in Sächsische Landesbibliothek - Staats- und Universitätsbibliothek in Dresden (SLUB, D-D1) with about 40 Dittersdorf's sources listed, containing many composer's autographs.

An important element of research on Dittersdorf's music is the observation of the presence of his pieces in the repertoire of church and monastery chapels in Poland and Silesia, the number of which is currently estimated at around 200. Similarly to ensembles in other Central European countries, primarily religious works and contrafacta of excerpts from stage works, symphonic and chamber music were registered. Thanks to the summarizing work of Remigiusz Pośpiech and later Alina Mądry, we can see the recent state of Dittersdorf's presence in the monastic and church repertoire. The largest collection of his works is stored in the Archive of the Pauline Fathers at Jasna Góra (according to the latest data contained in the RISM database there are 46 compositions in various genres) and has been described, among others by Paweł Podejko, Remigiusz Pośpiech and Alina Mądry. ${ }^{8}$ Thanks to the work of Polish researchers, we also learn about the performance of Dittersdorf's music in the following monastic centers in Poland:

- Dominican monastery in Gidle - now in: Library of the Dominican House of Studies. Archive of the Polish Province of the Dominicans in Kraków [Biblioteka Studium OO. Dominikanów. Archiwum Prowincji OO. Dominikanów w Krakowie] ${ }^{9}$

All figures from the RISM database are based on the data retrieved on November 1, 2019.

8 Paweł Podejko, Kapela wokalno-instrumentalna paulinów na Jasnej Górze (Kraków: Polskie Wydawnictwo Muzyczne, 1977); Paweł Podejko, Katalog tematyczny rękopisów i druków muzycznych kapeli wokalno-instrumentalnej na Jasnej Górze (Kraków: Wydawnictwo OO. Paulinów, 1991 = Studia Claromontana 12); Pośpiech, „Recepcja”, 232-235; Alina Mądry, Historia Muzyki Polskiej. Tom III, częśc 2: Barok 1697-1795. Muzyka religijna i jej barokowy modus operandi (Warszawa: Sutkowski Edition Warsaw, 2013), 420. The Jasna Góra collection is currently undergoing further catalogue work conducted by $\mathrm{PhD}$ students and students of the Institute of Musicology at the University of Wrocław under the direction of Remigiusz Pośpiech, Aleksandra Patalas and Agnieszka Drożdżewska as a part of the "Heritage of Polish Music" program implemented by the Fryderyk Chopin Institute in Warszawa.

9 Karol Mrowiec, Katalog muzykaliów gidelskich. Rękopisy muzyczne po kapeli klasztoru gidelskiego przechowywane w Archiwum Prowincji Polskiej OO. Dominikanów w Krakowie (Kraków: Archiwum Prowincji Polskiej OO. Dominikanów, 1986); Pośpiech, „Recepcja”, 235-237; Mądry, Barok, 429-430; Maciej Jochymczyk, „Repertuar kapeli oo. Dominikanów w Gidlach w świetle aktualnych badań, ze szczególnym uwzględnieniem źródeł osiemnastowiecznych” in Życie muzyczne w klasztorach dominikańskich w dawnej Rzeczpospolitej, ed. Aleksandra Patalas (Kraków: Musica 
- Cistercian monastery in Mogiła - now in: Archive and Library of the Cistercian Abbey in Mogiła [Archiwum i Biblioteka Opactwa Cystersów w Mogile $]^{10}$

- Benedictine Nuns monastery in Sandomierz - now in: Diocesan Library in Sandomierz [Biblioteka Diecezjalna w Sandomierzu] ${ }^{11}$

- Benedictine Nuns monastery in Staniątki ${ }^{12}$

- Jesuit monastery in Święta Lipka - now in: Bobolanum Library [Biblioteka Bobolanum] at the Jesuit College in Warsaw ${ }^{13}$

- Jesuit monastery in Otyń (Wartenberg) - now in: Museum of Musical Instruments in Poznań [Muzeum Instrumentów Muzycznych w Poznaniu] ${ }^{14}$ - St. Philip Neri Oratory monastery on the Holy Mountain in Gostyń. ${ }^{15}$

Information about the performance of Dittersdorf's music also comes from already structured and described collections of cathedral and collegiate centers in Poland. It is worth to list some of them, mostly with existing printed or digital catalogues or repertoire mentioned in dissertations:

Iagiellonica, 2016), 76-112. The revised catalog of musical sources from Gidle was developed as part of a project funded by the National Science Center $(\mathrm{NCN})$ by a team of researchers led by Aleksandra Patalas from the Institute of Musicology of the Jagiellonian University in Krakow and is available as a website (www.gidle.studiokropka.pl, access: 1.11.2019).

10 Pośpiech, „Recepcja”, 238; Mądry, Barok, 426; the RISM catalogue: Jolanta Byczkowska-Sztaba, Rękopisy i druki muzyczne z XVIII wieku w zbiorach Archiwum Opactwa Cystersów w KrakowieMogile. Katalog tematyczny (Warszawa, 2013, availabe on CD).

${ }^{11}$ Catalogue: Wendelin Świerczek, „Katalog rękopiśmiennych zabytków muzyki Biblioteki Seminarium Duchownego w Sandomierzu," Archiwa, Biblioteki i Muzea Kościelne 10 (1965), 223-278; Pośpiech, „Recepcja”, 239; Mądry, Barok, 434.

12 Tadeusz Maciejewski, Papiery muzyczne po kapeli klasztoru Panien Benedyktynek w Staniatkach (Warszawa: Instytut Wydawniczy Pax, 1984); Pośpiech, „Recepcja”, 239-240; Mądry, Barok, 327. The presence of Dittersdorf's instrumental music in the repertoire of Benedictine Nuns was also noted by Dariusz Smolarek, „Muzyka instrumentalna w polskich osiemnastowiecznych klasztorach sióstr benedyktynek" in Między traktatem a mowq uczuć w dźwięki przemienionq. Muzyka XVIII wieku w teorii i praktyce, ed. Małgorzata Grajter, Marek Nahajowski (Łódź: Akademia Muzyczna im. G. i K. Bacewiczów, 2014), 29-66; Dittersdorf's work is also mentioned in the monograph: Magdalena Walter-Mazur, Figura i fraktem. Kultura muzyczna polskich benedyktynek w XVII i XVIII wieku (Poznań: Poznańskie Towarzystwo Przyjaciól Nauk, 2014); English version: Magdalena Walter-Mazur, The Musical Culture of Polish Benedictine Nuns in the Seventeenth and Eighteenth Centuries, trans. Zofia Weaver (Berlin et al.: Peter Lang, 2018 = Eastern European Studies in Musicology, ed. Maciej Gołąb, 12) and the latest monograph of the monastery in Staniątki: Monografia zespotu muzycznego oraz katalog muzykaliów klasztoru ss. Benedyktynek w Staniatkach, ed. Marcin Konik (Kraków: Musica Iagiellonica, 2016).

13 Mądry, Barok, 430.

${ }_{14}$ Mądry, Barok, 305; see also: Patryk Frankowski, Alina Mądry, „An unknown collection of music manuscripts from Otyń (Wartenberg)”, Interdisciplinary Studies in Musicology 11 (2012), 67-80.

15 Danuta Idaszak, Muzyka u Księży Filipinów na Świętej Górze w Gostyniu (Gostyń: Księża Filipini, 2004). 
- Wawel Cathedral - now in: Archive and Library of the Kraków Cathedral Chapter [Archiwum i Biblioteka Krakowskiej Kapituły Katedralnej] in Kraków ${ }^{16}$

- Poznań Cathedral - now in: Archdiocesan Archive in Poznań [Archiwum Archidiecezjalne w Poznaniu $]^{17}$

- Gniezno Cathedral - now in: Archdiocesan Archive in Gniezno [Archiwum Archidiecezjalne w Gnieźnie $]^{18}$

- St. Anne's church in Kraków - musical sources not preserved ${ }^{19}$

- collegiate church in Pilica - now in church library $y^{20}$

- collegiate church of st. Maria Magdalena in Poznań - now in: Archdiocesan Archive in Poznań [Archiwum Archidiecezjalne w Poznaniu] ${ }^{21}$

- St. Benon's church in Warsaw (music not preserved) ${ }^{22}$ and other, smaller centres.

The list of church music heritage in Poland, containing Dittersdorf's repertoire as well, will surely be enlarged, as the inventory works are currently being performed or planned by the Polish researchers. It is needed to point out that Dittersdorf's music was catalogued also abroad in the work by Fr. Dariusz Smolarek SAC, summarizing the musical collection from the Piarist monastery in Podoliniec (now kept in National Archive in Bratislava, department in Modra, $\mathrm{SK}-\mathrm{MO}){ }^{23}$

16 Pośpiech, „Recepcja”, 237-238, see also: Jadwiga Prus, Muzyka na Wawelu (Kraków: Wydawnictwo Literackie, 1975); Tadeusz Przybylski, „Muzyka w liturgii katedry wawelskiej w czasach oświecenia i XIX wieku", in Tradycje muzyczne katedry wawelskiej, ed. by Jacek Berwaldt et al. (Kraków: Wydział Duszpasterstwa Kurii Metropolitalnej, 1985), 95-101. Dittersdorf's compositions only mentioned in the inventory.

17 Mądry, Barok, 121.

${ }^{18}$ In the 1960s, Władysław Zientarski conducted research on the sources from Gniezno, see: Pośpiech, „Recepcja”, 237; Mądry, Barok, 407. The catalogue of the collection of the Gniezno Cathedral by Danuta Idaszak, Źródta muzyczne Gniezna. Katalog tematyczny. Stownik muzyków (Kraków: Musica Iagellonica, 2001).

19 Pośpiech, „Recepcja”, 238; see also: Ernest Kubala, „Organy i nuty w kościele św. Anny w Krakowie według inwentarza z początku XIX wieku”, Muzyka 32, no. 1 (1978), 73-80.

${ }^{20}$ Mirosław Perz, „Kapela Zamoyskich i kolegiacka w Pilicy”, in Z dziejów muzyki polskiej (7), ed. Konrad Pałubicki (Bydgoszcz, 1964), 41-54.

${ }^{21}$ Mądry, Barok, 148, 409-411. Cataloguing of musical sources in progress.

${ }^{22}$ Ryszard Mączyński, „Koncerty u Benonitów. Z dziejów życia muzycznego Warszawy na przełomie XVIII i XIX wieku”, Muzyka 34, no. 4 (1989), 65-91; Ryszard Mączyński, Muzyka i teatr. Wkręgu kultury zakonnej Warszawy XVII-XIX wieku (Toruń: Wydawnictwo Naukowe Uniwersytetu Mikołaja Kopernika, 2018), 239, 267.

${ }^{23}$ Fr. Dariusz Smolarek SAC, „Muzykalia pijarskie z Podolińca w zbiorach Państwowego Archiwum w Modrej na Słowacji”, in Europejska kultura muzyczna w polskich archiwach i bibliotekach, ed. Aleksandra Patalas, Stanisław Hrabia (Kraków: Musica Iagiellonica, 2008), 71-138; Fr. Dariusz 
It should also be added that the research in the territories incorporated after 1945 to the Polish state has been conducted for many years by cataloguing teams in the largest libraries in Poland. Currently, the RISM database contains about 60 Dittersdorf compositions catalogued in the collections of the University Library in Warsaw (PL-Wu), from the former collection of the Musikalisches Institut bei der Universität Breslau, transformed after the war into the Department of Musicology at the University of Wrocław (1945-1952). Part of this collection, gathering many sources, mainly of Silesian provenance, contains works that testify to the composer's performance in churches and monasteries in Wrocław and the province. About 30 pieces from the collections of the University Library in Wrocław have been recorded in the RISM database. The latest catalogue work, conducted under the auspices of the "Fontes Musicae in Polonia" project, records newly discovered manuscripts of Dittersdorf music in Kłodzko (PL-KŁwnm; former Jesuit, later parish church with already 16 pieces listed). We cannot omit an equally important collection from Cistercian abbey in Krzeszów (PL-KRZ). Cataloguing works by the RISM group, operating at the University of Wrocław since 2011, will be presented later.

While describing secular collections, mostly from court or aristocratic centres, it is worth to mention, that the process of cataloguing is now in progress, and detailed information about Dittersdorf is being expected. In the context of works devoted to musical theater, the place of Dittersdorf's music in the Warsaw repertoire was marked by Alina Żórawska-Witkowska, discussing performances of operas and singles at the Royal Theater during the reign of Stanisław August in Warsaw. ${ }^{24}$ At this point, it is necessary to mention works by Irena Bieńkowska, dedicated to the musical collection of Sanguszko family in Sławuta. Preserved inventory of music shows a great popularity of Dittersdorf's symphonies, most numerous in the whole collection. ${ }^{25} \mathrm{~A}$ research on subsequent court collections belonging to the Polish aristocracy will certainly show the place of Dittersdorf's music in their daily repertoire. A little less is known about the role of the artist's works in the repertoire of public theaters. For example, the popularity of

Smolarek SAC, Katalog tematyczny muzykaliów z klasztoru pijarów w Podolińcu / Thematischer Katalog für Musikalien aus dem Piaristen-Kloster in Pudlein (Lublin: Wydawnictwo KUL, 2009).

${ }^{24}$ Alina Źórawska-Witkowska, Muzyka na dworze $i$ w teatrze Stanistawa Augusta (Warszawa: Ars Regia, 1995). The presence of Dittersdorf's theatrical works in Warsaw of the 18th century was earlier mentioned by Ludwik Bernacki, Teatr, dramat i muzyka za Stanistawa Augusta, t. 2 (Lwów: Zakład Narodowy im. Ossolińskich, 1925).

${ }^{25}$ Irena Bieńkowska, „Inwentarz muzykaliów sanguszkowskich z II połowy XVIII wieku”, Muzyka 62, no. 1 (2017), 48-89. 
Dittersdorf's singspiels has also reached Lviv, which was signaled by Michał Piekarski. ${ }^{26}$

More remarks about Dittersdorf's music can be found in the works by Polish musicologists dedicated to several repertoire genres in Polish musical culture. The lexical biographical entry developed by Alina Żórawska-Witkowska was a work summarizing the previous findings in this field from about the $1980 \mathrm{~s} .{ }^{27}$ Later after 2010, some observations about the presence of Dittersdorf's music in religious centers were given by Alina Mądry in her monography on the late baroque music in Poland. The profile of the repertoire, its apportionment and the two specific features (popularity of contrafactas and symphonies) are mentioned in the book. ${ }^{28} \mathrm{~A}$ first attempt to estimate the place of Dittersdorf's symphonic music in Poland at the end of the 18th century was made by Beata Stróżyńska in her monograph on the symphony. It indicates that after Joseph Haydn, Dittersdorf and Ignaz Pleyel were the most popular foreign artists, described as the 'golden trinity', as evidenced by the data taken from the Polish collections available at that time. Due to the subject of the work, the author merely points to the role of the composer in performing the symphony and publishing then available sources of his music. ${ }^{29}$ Mikołaj Rykowski also drew on Dittersdorf's work by extensively discussing the Harmoniemusik phenomenon during the Classicism period. In his work, one can find episodes taken from the artist's biography in the context of the social role of musicians and a broader background of the occurrence of Dittersdorf's music, covering the Czech and Austrian territories. ${ }^{30}$ Some remarks about the string quartets were given by Julia Gołębiowska, referring to the style and influence of Dittersdorf on Polish composers. ${ }^{31}$

The context of Dittersdorf's artistic activity appeared also in the research on the history of traditional music. Zbigniew Jerzy Przerembski in his monograph on bagpipes in the Old-Polish period examined the artist's autobiography, dictated by his son before his death, in which he described the circumstances of the employment of rural pipers to diversify one of the court pastimes and

${ }^{26}$ Michał Piekarski, Muzyka we Lwowie. Od Mozarta do Majerskiego. Kompozytorzy, muzycy, instytucje (Warszawa: Wydawnictwo Akademickie SEDNO, 2018).

27 Alina Żórawska-Witkowska, „Dittersdorf Karl”, Encyklopedia muzyczna PWM, ed. Elżbieta Dziębowska, Biographical Part „c-d” (Kraków: Polskie Wydawnictwo Muzyczne, 1984), 415-416.

${ }^{28}$ Mądry, Barok, 408, 427, 644-645, 652.

${ }^{29}$ Beata Stróżyńska, Symfonia w XVIII-wiecznej Polsce. Teoria, repertuar i cechy stylistyczne (Łódź: Akademia Muzyczna G. i K. Bacewiczów, 2015), 212-213, 217-218. Together with Polish sources the set of Dittersdorf's symphonies kept in Krzeszów in Silesia is presented in the book.

${ }^{30}$ Mikołaj Rykowski, Harmoniemusik - utwory na instrumenty dęte w zwierciadle epoki klasycyzmu (Toruń: Wydawnictwo Adam Marszałek, 2016).

${ }^{31}$ Julia Gołębiowska, „Kwartet smyczkowy w muzyce polskiej XIX wieku” (PhD diss., Katedra Muzykologii Uniwersytetu Adama Mickiewicza w Poznaniu, 2014). 
observed music playing in the inn with a band consisting of a 'Polish goat' and small bagpipes. ${ }^{32}$

The research on Dittersdorf's music is also conducted at the Department of Historical Musicology at the Institute of Musicology in Wrocław by Remigiusz Pośpiech and a team of researchers. The team's achievement was the preparation of a series of catalogues according to the RISM standard, including collections of the monastery of the Order of the Holy Sepulchre in Nysa (Neisse) and the ducal castle in Oleśnica (Oels), where Dittersdorf's work is strongly represented. ${ }^{33}$

In Wrocław new facts about the performance practice of Dittersdorf's music in Poland and Silesia were given in several works by Grzegorz Joachimiak. His contributions were dedicated to the Cistercian's collections from Obra and Krzeszów, ${ }^{34}$ tracing the unknown pieces from the collections of Silesian aristocracy in Cieplice (Warmbrunn) and Pszczyna (Pless). ${ }^{35}$ His recent explorations in Lviv resulted in the discovery of several symphonies from the Sapieha collection from castle in Krasiczyn. ${ }^{36}$ Information about subsequent manuscripts with Dittersdorf's music also came in thanks to the work of Ludmiła Sawicka, who described the inventory of music collections of Joseph Engel, organist and cantor from Gryfów Śląski (Greiffenberg), currently stored in the Capitular Library in

${ }^{32}$ Zbigniew Jerzy Przerembski, Dudy. Dzieje instrumentu w kulturze staropolskiej(Warszawa: Instytut Sztuki Polskiej Akademii Nauk, 2006), 110-111, 230. Jadwiga Sobieska (née Pietruszyńska) noticed this issue as early as 1936 in: Dudy wielkopolskie (Poznań, Instytut Zachodnio-Słowiański Uniwersytetu Poznańskiego, 1936), 60.

33 The catalogues are published in the series: "Thesaurus Musicorum in Silesia" by Remigiusz Pośpiech, Agnieszka Drożdżewska, Grzegorz Joachimiak and Ludmiła Sawicka. Two more collections in the series are from collegiate church of The Holy Cross in Opole and a collection of music by the 18th-century music directors of the Wrocław Cathedral. The works were financed through a subvention from the "National Programme for the Development of the Humanities" (2012-2017).

${ }^{34}$ Grzegorz Joachimiak, „Muzykalia z klasztorów cysterskich w Krzeszowie i Obrze; nieznane źródła z Krzeszowa. Sprawozdanie z prac w dniach 1 V 2013-30 X 2014 r.”, Hereditas Monasteriorum 5 (2014), 499-511

35 Grzegorz Joachimiak, „Rękopiśmienne tabulatury lutniowe z I połowy XVIII wieku ze zbiorów cystersów z Krzeszowa. Repertuar - praktyka wykonawcza - mecenat artystyczny”, (PhD diss., Instytut Muzykologii Uniwersytetu Wrocławskiego, 2016), 743-744; Grzegorz Joachimiak, Kapela dworska w ślaskiej Pszczynie (Pless, Pleß): wprowadzenie do rekonstrukcji repertuaru muzycznego (publication in preparation).

${ }^{36}$ Grzegorz Joachimiak, „Z zagadnień proweniencji muzykaliów z kolekcji Sapiehów z Krasiczyna zachowanych w zbiorach Lwowskiej Narodowej Naukowej Biblioteki Ukrainy im. Wasyla Stefanyka”, in VII Міжнародна наукова конференція „мистецька Культура: історія, теорія, методологія", Інститут досліджень бібліотечних мистецьких ресурсів, Львівська національна наукова бібліотека України імені В. Стефаника, 30 września 2019 [7th International Scientific Conference „Art Culture: History, Theory, Methodology”, Research Institute for Library's Art Resources, Vasyl Stefanyk National Scientific Library of Ukraine in Lviv, 30th September 2019] (publication in preparation). 
Wroclaw [Biblioteka Kapitulna we Wrocławiu]. This resource included religious compositions and operatic music. ${ }^{37}$ More about Dittersdorf presence in Silesia was also given by Agnieszka Drożdżewska in the paper about cataloguing works undertaken by German musicologists in Wrocław during the late 1920s, when new traces (sources now probably missing) were discovered in Duszniki Zdrój (Bad Reinerz), Wambierzyce (Albendorf) and Lwówek Śląski (Löwenberg). ${ }^{38}$

Detailed research on the Dittersdorf's music in the monastic centers was started in Silesia by already mentioned Remigiusz Pośpiech. His main work, including the work of the Vienesse master, is a monography about the music in the liturgy of the Catholic church in Silesia in 17th and 18th Centuries. ${ }^{39}$ Thanks to his research and several papers about the musical culture of the monastery of the Order of the Holy Sepulchre in Nysa (Neisse), more was revealed about the music cultivated in the area of Javorník. ${ }^{40}$ This topic was continuated by Agnieszka Drożdżewska, discussing literature and sources showing the composer's artistic contacts between the already mentioned convent in Nysa and the Piarists monastery in Bílá Voda. ${ }^{41}$ Dittersdorf's music is also present in the monography about the musical culture of the Jesuits in Silesia and Kłodzko County by Tomasz Jeż, with observations about the composer's place in the Jesuits liturgy, especially in preserved collection from the church in Kłodzko. ${ }^{42}$

${ }^{37}$ Ludmiła Sawicka, Muzykalia ze zbiorów Biblioteki Kapitulnej we Wroctawiu w świetle inwentarza Josepha Engla, Tradycje ślaskiej kultury muzycznej, t. XIII, ed. Andrzej Wolański et al. (Wrocław: Akademia Muzyczna im. Karola Lipińskiego, 2015), 131-144.

${ }_{38}$ Agnieszka Drożdżewska, „The cataloguing of musical sources in Silesia by German musicologists from the University of Wrocław during the first half of the twentieth century", Interdisciplinary Studies in Musicology 11 (2012), 23-40.

${ }^{39}$ Remigiusz Pośpiech, Muzyka wielogtosowa w celebracji eucharystycznej na Ślasku w XVII i XVIII wieku (Opole: Redakcja Wydawnictw Wydziału Teologicznego Uniwersytetu Opolskiego, 2004)

${ }^{40}$ Remigiusz Pośpiech, „Tradycje muzyczne nyskich bożogrobców”, Człowiek i Kościót w dziejach. Ksiega pamiątkowa dedykowana księdzu profesorowi Kazimierzowi Doli, ed. Jan Kopiec, Norbert Widok (Opole: Redakcja Wydawnictw Wydziału Teologicznego Uniwersytetu Opolskiego, 1999), 119-128; Remigiusz Pośpiech, „Muzykalia kościoła świętych Piotra i Pawła w Nysie przed i po sekularyzacji”, Sekularyzacja dóbr kościelnych na Górnym Ślasku w 1810 roku, ed. ks. Franciszek Wolnik (Opole: Redakcja Wydawnictw Wydziału Teologicznego Uniwersytetu Opolskiego, 2011), 59-84; Katalog tematyczny muzykaliów po kapeli klasztoru bożogrobców w Nysie, ed. Remigiusz Pośpiech (Lublin: Polihymnia 2012 = Thesaurus Musicorum Silesiae, 1).

${ }^{41}$ Agnieszka Drożdżewska, „Kontakty artystyczne Carla Dittersa von Dittersdorfa ze śląskimi klasztorami pijarów w Bílej Vodzie i bożogrobców w Nysie”, Liturgia Sacra 23, no. 1 (2017), 191-202.

${ }^{42}$ Tomasz Jeż, Kultura muzyczna jezuitów na Ślasku i ziemi kłodzkiej (1581-1776) (Warszawa: Wydawnictwo Naukowe Sub Lupa, 2013); English version: Tomasz Jeż, The Musical Culture of the Jesuits in Silesia and the Ktodzko County (1581-1776), transl. Tomasz Zymer (Berlin et al.: Peter Lang, 2019 = Eastern European Studies in Musicology, ed. Maciej Gołąb, 11). 
The broad context of Dittersdorf's religious music in Silesia was also examined by Fr. Piotr Tarlinski in the context of theological remarks. ${ }^{43}$

Dittersdorf's operatic repertoire permeated the sacred sphere. Attention was paid to this phenomenon while discussing church and monastery collections, including in the context of the Pauline ensemble in Jasna Góra. ${ }^{44}$ One of the most characteristic features of the monastery repertoire at that time, was the popularity of opera contrafactas, a practice that began in the late Baroque. In Poland and Silesia this practice was also very popular in the context of Dittersdorf's music. This topic was for example taken up in the master thesis by Aleksandra Redziak at the Institute of the Musicology in Wrocław, who also critically edited selected arias from the Nysa collection. ${ }^{45}$ Currently, Tomasz Fatalski at the Institute of Musicology in Warsaw runs an intensive exploration of Dittersdorf's solo arias, preserved in the collections of the University Library in Warsaw [Biblioteka Uniwersytecka w Warszawie]. He not only prepares a master thesis about the arias from the collections of Wrocław monasteries (now kept in Warsaw) but also accomplished editions of 20 arias. $^{46}$

Silesia became a very important area in the context of Dittersdorf's operatic activity as well. His stage works from the 1770s and 1780s were written for the bishop's theatre in Javorník, meanwhile he created the greatest singspiels for Vienna which were also transmitted to Wrocław and the whole region. After Maria Zduniak's first source research, more observations on the performance practice were given by Wojciech Kunicki in his paper dedicated to the Hieronymus Knicker tradition in local theatre at the beginning of the 19th century. ${ }^{47}$ As the continuation of the works by Hubert Unverricht, the topic of the late

${ }^{43}$ Fr. Piotr Tarlinski, „Dittersdorf Kirchenmusik in Schlesien. Theologische Anmerkungen” in Carl Ditters von Dittersdorf. Z $\dot{z} y c i a, 207-227$.

${ }_{44}$ Pośpiech, „Recepcja”, 231.

45 Aleksandra Redziak, „Arie Carla Dittersa von Dittersdorfa ze zbiorów po kapeli bożogrobców w Nysie. Rekonstrukcja i analiza wybranych przykładów" (Master thesis, Instytut Muzykologii Uniwersytetu Wrocławskiego, 2018). Two arias from the Nysa collection, edited by Aleksandra Redziak, were performed by Jolanta Kowalska-Pawlikowska (soprano) and the Capella Cracoviensis under the direction of Jan Tomasz Adamus during the 4th Miechów Days of Jerusalem on September 17, 2016 in Miechów.

${ }_{46}$ Tomasz Fatalski, „Antyfony Salve Regina Carla Dittersa von Dittersdorfa ze zbiorów Biblioteki Uniwersyteckiej w Warszawie - analiza porównawcza" (Bachelor thesis, Instytut Muzykologii Uniwersytetu Warszawskiego, 2018). Four arias edited by Tomasz Fatalski were performer during the 27th International Carl Ditters von Dittersdorf Festival in the monastic church in Bílá Voda on September 21, 2019 by Anna Začalová (soprano) and Václava Krejčí Housková (mezzosoprano) and Camerata Moravia led by Petr Chromčák.

${ }^{47}$ Wojciech Kunicki, „Einige Bemerkungen zu der Praxis der Dittersdorfschen Aufführung von Hieronymus Knicker in Breslau zu Anfang des 19. Jahrhunderts", in Carl Ditters von Dittersdorf. Z życia, 121-128. 
stage compositions by Dittersdorf was undertaken by Agnieszka Drożdżewska in her publications about musical life at the Brunswick court (1792-1805) in Oleśnica. ${ }^{48}$ Detailed information about preserved sources from the court theatre and orchestra were published in RISM in cooperation with SLUB Dresden, as well as in the form of printed catalogue. The author is already preparing a thesis about operatic life in Silesia, containing the characteristics of Dittersdorf's operas and singspiels written for Javorník and Oleśnica.

The last, although currently the most intensively explored area to be mentioned here, is the Dittersdorf's symphonic work, subjected to thorough source and style analysis by Miłosz Kula, a musicologist and conductor associated with the Music Academy of K. Lipiński in Wrocław and the Institute of Musicology at the University of Wrocław. He has already finished his doctoral thesis dedicated to the various aspects of orchestral works and its performance. ${ }^{49}$ Among his publication, it is worth to mention two papers describing the present state of sources with Dittersdorf's symphonies kept in Poland and in Dresden, ${ }^{50}$ as well as papers discussing the composer as a Silesian symphonist and his musical language. ${ }^{51}$ Recently, Miłosz Kula is completing his second doctoral thesis, dedicated to Dittersdorf's symphonies and their reception in Poland and Silesia. Research on the artist's symphonic creativity was also carried out at the Department of Musicology at the Adam Mickiewicz University in Poznań ${ }^{52}$ and in the Institute of Musicology at the University of Warsaw. ${ }^{53}$ Finally it is needed to mention,

${ }^{48}$ Agnieszka Drożdżewska, „Muzyka w teatrze dworskim księcia Fryderyka Augusta Brunszwickiego w Oleśnicy”, Muzyka 52, no. 3 (2007), 49-74; Agnieszka Drożdżewska, Kultura muzyczna Oleśnicy w XIX i pierwszej potowie XX wieku (Katowice: Edycja - Książki Naukowe i Specjalistyczne, 2017; Muzykalia dawnej Biblioteki Zamkowej w Oleśnicy. Katalog zachowanych zbiorów, ed. Agnieszka Drożdżewska (Lublin: Polihymnia, 2017 = Thesaurus Musicorum Silesiae, 4).

${ }^{49}$ Miłosz Kula, „Śląskie symfonie Carla Dittersa von Dittersdorfa. Historia - teoria - praxis” (PhD diss., Akademia Muzyczna im. K. Szymanowskiego w Katowicach, 2017). The author edited four Dittersdorf's symphonies, one of them were performer in Silesian Philharmony in Katowice conducted by Miłosz Kula on June 3, 2017.

${ }^{50}$ Miłosz Kula, „Stan zachowania rękopisów symfonii Carla Dittersa von Dittersdorfa w Polsce - rekonesans", Kwartalnik Mtodych Muzykologów UJ 29, no. 2 (2016), 92-119; Miłosz Kula, "The Collection of Manuscripts of Carl Ditters von Dittersdorf's Symphonies from Sächsische Landesbibliothek - Staats- und Universitätsbibliothek Dresden”, Kwartalnik Mtodych Muzykologów UJ 35, no. 4 (2017), 63-92.

${ }^{51}$ Miłosz Kula, „Carl Ditters von Dittersdorf - pierwszy śląski symfonik?”, in Tradycje Ślaskiej Kultury Muzycznej, ed. Anna Granat-Janki, t. XIV, p. 2, (Wrocław: Akademia Muzyczna im. Karola Lipińskiego, 2017), 343-356; Miłosz Kula, Idiomatyczne cechy języka muzycznego symfonii Carla Dittersa von Dittersdorfa (publication in preparation).

${ }^{52}$ Karolina Kaźmierczak, „Symfonia in A Karla Dittersa von Dittersdorfa. Analiza i edycja źródłowa” (Bachelor thesis, Katedra Muzykologii Uniwersytetu Adama Mickiewicza w Poznaniu, 2014).

53 Piotr Wojciechowski, „Carl Ditters von Dittersdorf i jego symfonia Die Befreyung Andromedens z cyklu Symfonii Owidiuszowych” (Bachelor thesis, Instytut Muzykologii Uniwersytetu 
that Dittersdorf's music kept in Polish archives is starting to be edited and performed. An important role is played by the Musica Claromontana recording series, published under the auspices of the president of the „Kapela Jasnogórska” Association in Jasna Góra (headed by Fr. Nikodem Kilnar). Four arias and six symphonies by Dittersdorf, edited from the monastery archive, have already been recorded, reflecting special interest in operatic (mainly Neapolitan) and orchestral repertoire. $^{54}$

This study, written 20 years after the first summary by Remigiusz Pośpiech, certainly doesn't fill the topic of research on the Dittersdorf's music, run by Polish researchers, due to the extraordinary popularity and universality of his works in music centers of various types. It can be seen, however, that research into the life and work of Dittersdorf seems to be more and more intensively developed in recent years, also thanks to the youngest group of scholars. Researchers are facing many tasks for the future, including the urgent need to launch the modern editions of the works of Dittersdorf ${ }^{55}$ and to complete the bibliographic and thematic catalogue of his works. These issues remain in the further plans of Wrocław musicologists, due to the artist's personal contacts with the Silesia region and stays in Wrocław, Nysa and Oleśnica. It is necessary that the knowledge of his work should be developed and disseminated, just as his music was popular everywhere in the Commonwealth and Silesia.

\section{Recent State of Research on the Life and Work of Carl Ditters von Dittersdorf in Poland}

\section{Abstract}

The paper presents the current state of research conducted by Polish scholars in the field of exploration and analysis of sources related to the work of Carl Ditters von Dittersdorf. This Vienesse-based composer played an important role in shaping the image of musical culture of Silesia at the end of the 18th century,

Warszawskiego, 2014).

54 Jasnogórska Muzyka Dawna / Musica Claromontana, vol. 55, recorded by Katarzyna Dondalska (soprano) and Early Music Ensemble Capella Claromontana conducted by Tomasz Wabnic, with booklet text by Agnieszka Drożdżewska, „Na skrzyżowaniu sacrum i profanum. Opera wirtuozeria - kosmopolityzm II pol. XVIII wieku”. The second CD with Dittersdorf's music is in progress, with booklet text by Aleksandra Patalas.

55 This scientific task was indicated as an important element for the reviving musicology in Wroclaw by Christoph-Hellmut Mahling during the conference in 2003. See "Perspektywy muzykologii we Wrocławiu - dyskusja”, ed. Joanna Gul and Monika Janowiak-Janik, in Muzykologia we Wroctawiu. Ludzie - bistoria - perspektywy, ed. Maciej Gołąb (Wrocław: Wydawnictwo Uniwersytetu Wrocławskiego, 2005), 147. 
especially due to his activity as a director of music at the bishop's court in Javorník castle. Another reason was his artistic contacts with most important cultural centers of the entire region, such as Wrocław, Nysa, Bílá Voda and Oleśnica.

First remarks concerning preserved sources on Dittersdorf in Poland appeared in 1960s in various papers on several different musical collections. Inspired by the activity of German (Hubert Unverricht) or Czech (Rudolf Zuber) researchers, comprehensive source studies on Dittersdorf were initiated at the turn of the 20th and the 21st Century in Poland: Maria Zduniak at the Academy of Music in Wrocław aimed attention at contacts between Dittersdorf and Wrocław, while Piotr Tarlinski and Remigiusz Pośpiech at the University of Opole set his work in the wider context of Silesian and Polish music culture. The initial focus on sources from various Silesian centers (e.g. Wrocław, Oleśnica, Nysa, Kłodzko, Krzeszów) was later extended to other music collections in Poland. As it turned out, the work of Dittersdorf (mainly symphonies, opera arias and church music) constituted an important part of music collections from various regions of Poland (e.g. Jasna Góra, Kraków-Mogiła, Gidle, Staniątki and other). This circumstance enabled broader research in the field of music reception.

Currently, the research on various aspects of the work of Carl Ditters von Dittersdorf is being conducted at the Institute of Musicology at the University of Wrocław by Remigiusz Pośpiech (religious music, especially in Silesian monasteries, reception of works in Silesia and Poland), Agnieszka Drożdżewska (late stage works for the ducal stage in Oleśnica, contrafacta from the monastery collections, artistic contacts with Silesian centers), and Miłosz Kula (sources and reception of symphonies). Bachelor and master theses on Dittersdorf's music also appear in musicological centers at the universities in Warsaw, Wrocław, Poznan and Kraków, which shows a gradual increase of the interest in this topic. Works by Dittersdorf, preserved in Polish archives and libraries, are also gradually becoming available to a wider audience through the CD-recording series, including the project Musica Claromontana. 


\section{Současný stav bádání o životě a díle Carla Ditterse von Dittersdorfa v Polsku}

\section{Abstrakt}

Studie představuje současný stav bádání prováděného polskými vědci v oblasti výzkumu a analýzy pramenů souvisejících s dílem Carla Ditterse von Dittersdorfa. Tento vídeňský skladatel hrál důležitou roli při utváření obrazu hudební kultury Slezska na konci 18. století, zejména díky své funkci vedoucího hudebního souboru na biskupském dvoře na zámku Javorník. Dalším důvodem byly jeho umělecké kontakty s nejdůležitějšími kulturními centry celého regionu, jako jsou Wrocław (Vratislav), Nysa, Bílá Voda a Oleśnica.

První poznámky o dochovaných dittersdorfovských pramenech v Polsku se objevily v 60 . letech 20 . století ve studiích zaměřených na některé hudební sbírky. Na základě podnětů německých (Hubert Unverricht) a českých (Rudolf Zuber) muzikologů byl na přelomu 20. a 21. století zahájen komplexní pramenný výzkum: Maria Zduniak z Akademie múzických umění ve Vratislavi zaměřila pozornost na kontakty mezi Dittersdorfem a Vratislaví, zatímco Piotr Tarlinski a Remigiusz Pośpiech z Opolské univerzity pojednali Dittersovo dílo v širším kontextu slezské a polské hudební kultury. Původní zaměření na prameny z různých slezských center (např. Wrocław, Oleśnica, Nysa, Kłodzko, Krzeszów) bylo později rozširreno na další hudební sbírky v Polsku. Jak se ukázalo, Dittersdorfovo dílo (zejména symfonie, operní árie a církevní hudba) představovalo důležitou součást hudebních sbírek z různých polských regionů (např. Jasna Góra, KrakówMogiła, Gidle, Staniątki a další). Tato okolnost umožnila širší výzkum v oblasti recepce Dittersovy hudby.

V současné době probíhá výzkum různých aspektů tvorby Carla Ditterse von Dittersdorfa na Institutu hudební vědy Vratislavské univerzity: Remigiusz Pośpiech se věnuje duchovní hudbě (zejména ve slezských klášterech) a dittersovské recepci ve Slezsku a Polsku, Agnieszka Drożdżewska se zabývá pozdní jevištní tvorbou pro vévodské divadlo v Oleśnici, kontrafakty z klášterních sbírek a uměleckými kontakty se slezskými středisky a Miłosz Kula prameny a recepcí Dittersových symfonií. Bakalářské a diplomové práce o Dittersdorfově hudbě se objevují také na muzikologických pracovištích na univerzitách ve Varšavě, Vratislavi, Poznani a Krakově, což ukazuje na postupný nárůst zájmu o toto téma. Dittersdorfova díla uchovávaná v polských archivech a knihovnách jsou postupně zpř́istupňována širšímu publiku prostřednictvím $\mathrm{CD}$ nahrávek, včetně projektu Musica Claromontana. 


\title{
Keywords
}

Carl Ditters von Dittersdorf; Poland; Silesia; Wrocław; state of research; source studies; musicology; opera; church music; symphonies; cataloguing

\section{Klíčová slova}

Carl Ditters von Dittersdorf; Polsko; Slezsko; Wrocław (Vratislav); stav bádání; pramenné studie; muzikologie; opera; chrámová hudba; symfonie; katalogy

\author{
Agnieszka Drożdżewska \\ Instytut Muzykologii Uniwersytetu Wrocławskiego \\ Institute of Musicology, University of Wrocław \\ agnieszka.drozdzewska@uwr.edu.pl
}

